\title{
Groundwater vulnerability assessment of Hoshangabad and Budni industrial area, Madhya Pradesh, India, using geospatial techniques
}

\author{
Rakesh Ahirwar ${ }^{1,2}$ (D) Mohammad Subzar Malik ${ }^{2} \cdot$ Jai Prakash Shukla ${ }^{1,2}$
}

Received: 22 March 2019 / Accepted: 26 February 2020 / Published online: 7 March 2020

(c) The Author(s) 2020

\begin{abstract}
The quality of groundwater can be determined by hydrogeological formations which vary geographically. Subsurface geology has significant role in governing the movement and quality of groundwater. The present study aims assessment of groundwater contamination vulnerability in Hoshangabad and Budni industrial area using the DRASTIC model approach. The model is hybridization of the seven parameters that provides input to the model. In the model, rating and weightage to each parameter were assigned as per the relative significance of the parameter in groundwater contamination. Groundwater contamination vulnerability index (GWVI) has been computed by integrating of these data layers in ArcGIS environment. The obtained GWVI in the area varies from 66 to 170, which was further divided into five zones, i.e. (1) very low GW contamination zone, (2) low GW contamination zone, (3) moderate GW contamination zone, (4) high GW contamination zone and (5) very high GW contamination zone. Further, the model has been validated by analysing the sulphide concentration in groundwater of the delineated GW contamination vulnerable zones. The model has been found effective for the prevailing hydrogeological settings of the area. The model can serve as an effective tool for the concerned authority, social workers and government/ non-organizations for the management of groundwater resources in the area. Further, application of the GIS technique has been found useful in preparing the database of each variable of the model.
\end{abstract}

Keywords DRASTIC model · Groundwater contamination vulnerability index $\cdot$ Geological setting $\cdot$ ArcGIS $\cdot$ Hoshangabad and Budni industrial area

\section{Introduction}

Groundwater is an indispensable substance to humankind for the sustenance of life on the earth (Gordon et al. 2008) that should be managed properly (Samake et al. 2011; Gupta 2014) by employing new scientific methods. The presence and quality of water depends upon geographical location. Our globe contains total 1400 million cubic kilometre area, out of which $97 \%$ is covered by oceans as saline water, $2 \%$ is present in the form of solid (locked in ice caps and glaciers) and the remaining $1 \%$ fresh water flows in lakes, rivers, ponds, wells, etc. Half part of the fresh water is stored as

Rakesh Ahirwar

gis07rakesh@gmail.com

1 Academy of Scientific and Innovative Research (AcSIR), CSIR-Advanced Materials and Processes Research Institute (CSIR-AMPRI) Campus, Bhopal, Madhya Pradesh 462026, India

2 CSIR-AMPRI, Bhopal, Madhya Pradesh 462026, India groundwater (Balasubramanian 2015). The term groundwater vulnerability is related to the groundwater contamination process and its harmful factors (Qian et al. 2012). Groundwater vulnerability to contamination term was first coined by Margat (1968). Groundwater vulnerability to contamination concept depends on the assumption where physical, environmental and human activities are against to groundwater (Prasad and Shukla 2014). Groundwater hazard evaluation can be described as calculation capacity of the area to the contamination from the nearby surface up to the groundwater (Rebolledo et al. 2016). It is the very helpful factor for the proper land use and sustainable natural management (Ghosh et al. 2015).

Maps of aquifer contamination vulnerability are in high demand and serve as useful tool because groundwater is the main source of drinking water in many parts of the globe (Neshat et al. 2014a, b; Shrestha et al. 2016). The high rate of groundwater consumption in different sectors, e.g. domestic, industrial and agricultural, became the potential cause of decline in water table as well as sources of groundwater 


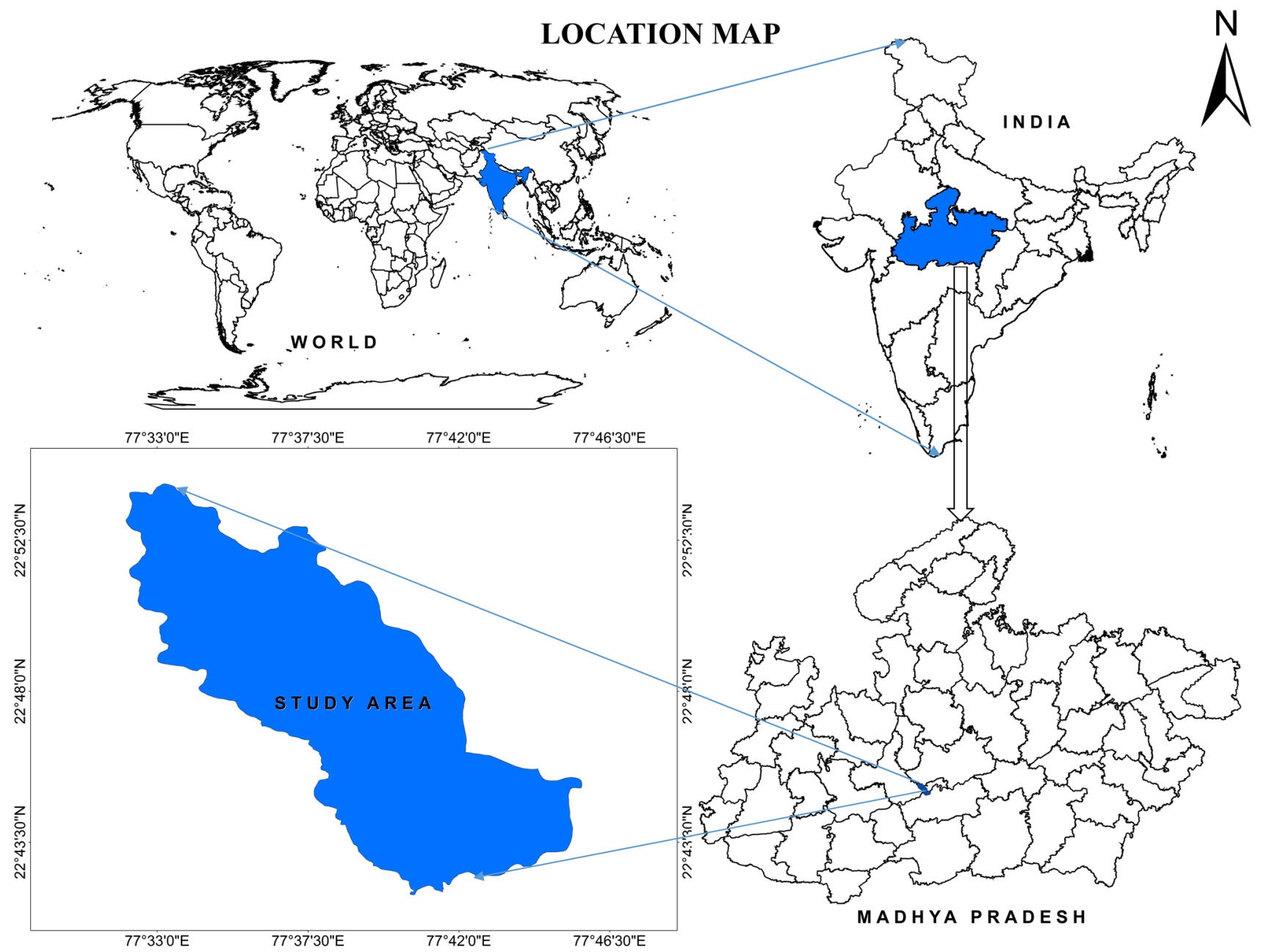

Fig. 1 Location map

contamination. The contamination of aquifers due to human or natural interferences is one of the emerging and biggest environmental concerns in both urban and industrial areas (Aller et al. 1984; Harlow and Lecain 1993; Alwathaf and El Mansouri 2011; Tirkey et al. 2013). Therefore, there is keen requirement to conduct scientific research studies to tackle this growing environmental challenge (Rahman 2008). DRASTIC model approach which works on the hydrogeological settings of an area gives some advantages between these studies (Huang et al. 2018; Ahirwar and Shukla 2018; Malik and Shukla 2019). The model uses the hydrogeological parameters such as depth to water, net recharge, aquifer media, soil media, topography, impact of vadose zone and hydraulic conductivity as input parameters of the model in order to compute the groundwater vulnerability index (Aller et al. 1987; Rosen 1994; Baalousha 2006; Sener et al. 2009; Mogaji et al. 2014; Chandrasekar et al. 2014).

Groundwater vulnerability assessment plays a vital role in the utilization and aegis of groundwater resources
(Antonakos and Lambrakis 2007; Meng et al. 2011). DRASTIC model working in association with GIS has become a widely acceptable method for impressive management and planning of groundwater resources (Secunda et al. 1998; Sinha et al. 2016). DRASTIC model is used for detailed groundwater contamination vulnerability mapping while assigning rating to each parameter multiplying with the given weightage in ArcGIS (Al-Rawabdeh et al. 2014; AlZabet 2002; Jaseela et al. 2016). The model included the use of statistical and geo-statistical method for the amendment of the parameter ratings and weightage of each DRASTIC parameter in a GIS environment (Panagopoulos et al. 2006). Groundwater contamination vulnerability maps generated by DRASTIC model are helpful in monitoring of groundwater quality, identification of the areas that require more care to prevent them from contamination, aquifer management and land use planning (Jasrotia and Singh 2005; BojórquezTapia et al. 2009; Baalousha 2016). DRASTIC model provides us the information about the area which is prone to 
Table 1 Data source and format of data

\begin{tabular}{llll}
\hline S. no. & Parameters & Sources & Format of data \\
\hline 1. & Groundwater level & Primary data (through well inventory) & Map \\
2. & Net recharge & Secondary data LISS III Image & Map \\
3. & Lithology map & Secondary data (District Resource Map Published by GSI, 2003) & Map \\
4. & Soil map & Secondary data (National Bureau of Soil Survey and Land use Planning, & Map \\
& & ICAR) (NBSS Publ.59) & Map \\
5. & Slop map & Secondary data SRTM satellite data & Map \\
7. & Impact of vadose zone & Secondary data (District Resource Map Published by GSI, 2003) & Map \\
\hline
\end{tabular}

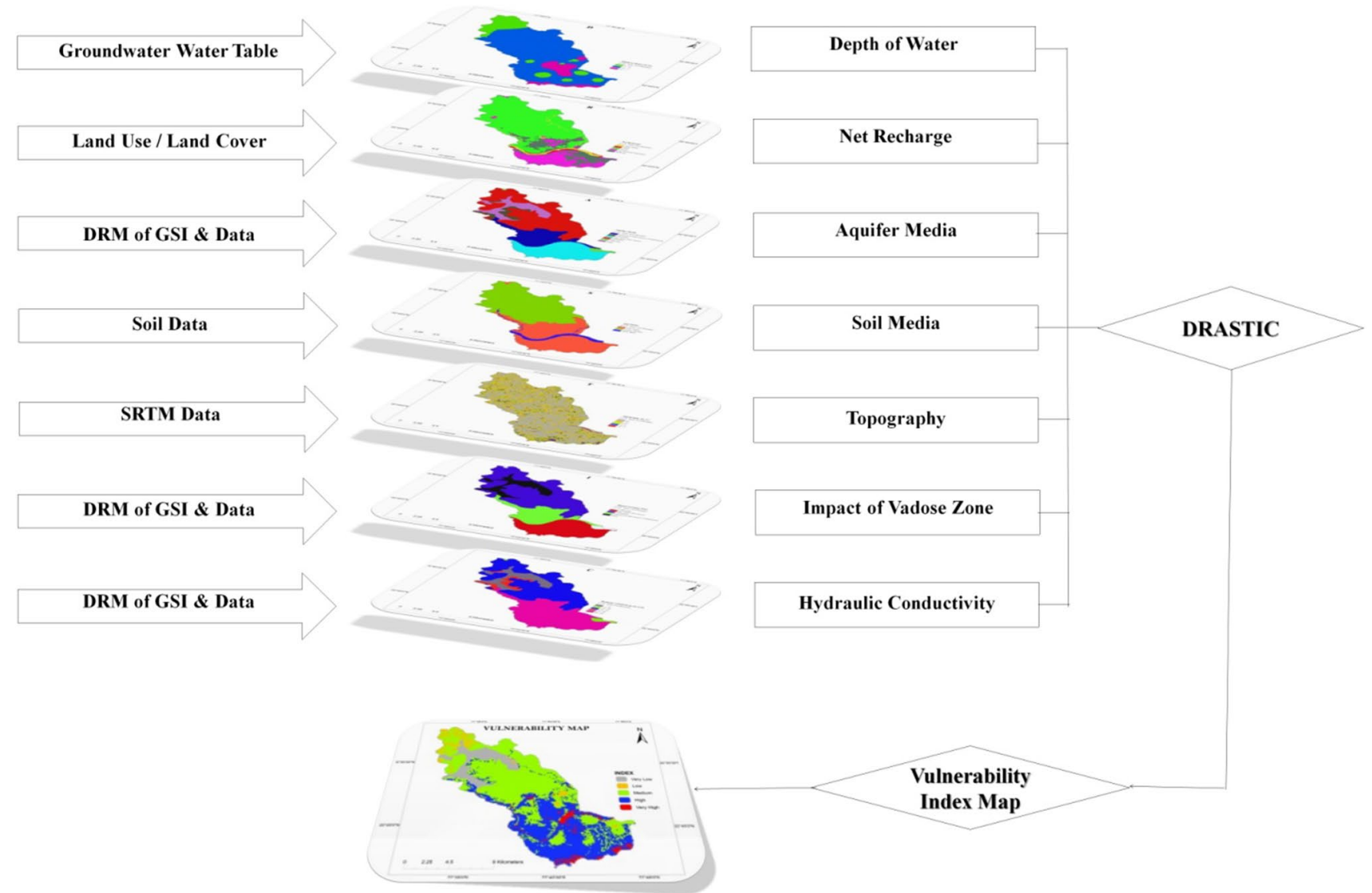

Fig. 2 Methodology flow chart

groundwater contamination by classifying them into low, moderate and high contamination zones (Leone et al. 2009). All these classes describe the probability of groundwater contamination potential in the area (Al-Rawabdeh et al. 2013; Kumar et al. 2016). The weightage and rating of each parameter comprise a GIS map layer. All the map layers were integrated to demarcate the final output, i.e. groundwater contamination vulnerability map (Fritch et al. 2000; Yin et al. 2013; Albinet 1970; Bai et al. 2012; Hamza et al. 2007).
Geospatial technology is an emerging technology in the field of hydrological sciences which helps in assessing, monitoring and managing of groundwater resources on large scale (Kaliraj et al. 2015; Kanade and Bhattacharya 2016). Groundwater being a limited resource is going exploited at rapid pace due to its maximum consumption in various sectors over years that leads to decrease its potentiality (Prasad et al. 2011). Currently, the contamination of groundwater is a big environmental concern resulted due to the rapid expansion of urbanization, industrialization, improper 
Table 2 Assigned rating and weightage to DRASTIC parameters

\begin{tabular}{|c|c|c|c|c|}
\hline DRASTIC parameters & Range & Rating & Weight & Index \\
\hline \multirow[t]{3}{*}{ Depth of water (D) } & $05-10$ & 7 & 5 & 35 \\
\hline & $10-15$ & 5 & & 25 \\
\hline & $>15$ & 3 & & 15 \\
\hline \multirow[t]{5}{*}{ Net recharge $(\mathrm{R})$} & Built-up & 1 & 4 & 4 \\
\hline & Agriculture (including crop and fallow land) & 3 & & 12 \\
\hline & Forest & 4 & & 16 \\
\hline & Water body & 8 & & 32 \\
\hline & Sand & 7 & & 28 \\
\hline \multirow[t]{6}{*}{ Aquifer media (A) } & Alluvium & 5 & 3 & 15 \\
\hline & Calcareous sand, gravel, conglomerate & 9 & & 27 \\
\hline & Sandstone & 6 & & 18 \\
\hline & Shale & 2 & & 6 \\
\hline & Silt, sand, clay, gravel & 7 & & 21 \\
\hline & Limestone & 8 & & 24 \\
\hline \multirow[t]{2}{*}{ Soil media (S) } & Fine loamy & 2 & 2 & 4 \\
\hline & Loamy skeletal & 5 & & 10 \\
\hline \multirow[t]{5}{*}{ Topography (T) } & $0-2$ & 10 & 1 & 10 \\
\hline & $2-6$ & 9 & & 9 \\
\hline & $6-12$ & 5 & & 5 \\
\hline & $12-18$ & 3 & & 3 \\
\hline & $18+$ & 1 & & 1 \\
\hline \multirow[t]{6}{*}{ Impact of vadose zone (I) } & Alluvium & 8 & 5 & 40 \\
\hline & Calcareous sand, gravel, conglomerate & 5 & & 25 \\
\hline & Sandstone & 6 & & 30 \\
\hline & Shale & 3 & & 15 \\
\hline & Silt, sand, clay, gravel & 7 & & 35 \\
\hline & Limestone & 6 & & 30 \\
\hline \multirow[t]{5}{*}{ Hydraulic conductivity (C) } & $>20$ & 3 & 3 & 9 \\
\hline & $20-40$ & 4 & & 12 \\
\hline & $40-60$ & 7 & & 21 \\
\hline & $60-80$ & 8 & & 24 \\
\hline & $80-100$ & 10 & & 30 \\
\hline
\end{tabular}

disposal of municipal and domestic waste, untreated waste and the uncontrolled growth of population. In rural areas, the application of fertilizers, pesticides, farm waste, etc., are the continuous sources of groundwater pollution (Kim and Hamm 1999). The vulnerability assessments of groundwater provide a scale of sensitivity of groundwater quality to an imposed contaminant and are globally accepted as a necessary element of aquifer management and protection (Ckakraborty et al. 2007; Brindha and Elango 2015). GIS practices have delivered a capable tool for evaluating and analysing the groundwater contamination potential of an area (Hasiniaina et al. 2010). The present study recommends that the model can be used as an effective tool for the management of this precious natural resource (Hamza et al.
2015; Barroso et al. 2015) and increases the sustainability of this everlasting natural source of water.

\section{Study area}

The study area covers parts of Hoshangabad and Sehore districts of Madhya Pradesh, India. The study area has occupied total geographical area $217.13 \mathrm{~km}^{2}$. The area falls in survey of India toposheet no's $55 \mathrm{~F} / 9,55 \mathrm{~F} / 10$ and 55 $\mathrm{F} / 13$, located between $22^{\circ} 42^{\prime} 30^{\prime \prime} \mathrm{N}-22^{\circ} 53^{\prime} 30^{\prime \prime} \mathrm{N}$ latitude and $77^{\circ} 31^{\prime} 00^{\prime \prime}-77^{\circ} 47^{\prime} 30^{\prime \prime} \mathrm{E}$ longitude. In the area, three large industries, viz Security Paper Mill (SPM), Abhishek and Vardhman Fabrics textile, are functioning from which huge amount of industrial waste and effluents comes out on daily basis. The industrial wastewater draining from these factories contains a number of harmful chemicals and salts which inflow through the soil and added directly 




Fig. 3 Depths to water level

or indirectly into the groundwater. Thus, the study has found the scope of groundwater contamination probability in the area (Thukral and Rahman 2017; Census of India, Hoshangabad district 2011). Therefore, DRASTIC model approach has been employed which works for aquifer contamination vulnerability assessment by evaluating the hydrological and topographical conditions of the area. The location map of the area is presented Fig. 1.

\section{Materials and method}

\section{DRASTIC modelling}

In the study, DRASTIC model in association with geographical information system (GIS) has been used to assess the aquifer pollution potential in Hoshangabad and Budni industrial area. The model has been developed by US Environmental Protection Agency (EPA) with aim to determine the pollution potential of aquifers in the USA (Aller et al. 1987). Currently, this is the most widely used method for the assessment of aquifer contamination vulnerability. The model is formed by combination of seven hydrogeological parameters, viz $\mathrm{D}=$ depth of water table, $\mathrm{R}=$ net recharge, $\mathrm{A}=$ aquifer media, $\mathrm{S}=$ soil media, $\mathrm{T}=$ topography, $\mathrm{I}=$ impact of vadose zone and $\mathrm{C}=$ hydraulic conductivity which are working in coordination to assess the aquifer pollution potential (Al Hallaq and Elaish 2012; Ghazavi and Ebrahimi 2015). In the present study, data of each model parameter have been collected from various sources. Depth to water level has been collected from well-inventory data (bore/tub well) during field survey. Net recharge has been computed from land use/land cover, and aquifer media has been extracted from lithology of the area, which has been derived by processing of the District Resource Map (DRM), GSI 2002. Soil media data have been taken from soils of Madhya Pradesh map, National Bureau of soil survey and land use planning (NBSS and LUP 1996). Slope has been extracted by processing of Shuttle Radar Topography Mission (SRTM) imagery in ArcGIS. Impact of vadose zone has been studied from the lithological cross section (rock type), and hydraulic conductivity has been taken from the given values for the different rock/soil materials of (Rahman 2008) Table 2. Rating and weightage to each variable has been assigned as per their relative susceptibility to groundwater contamination. Weightage to each 


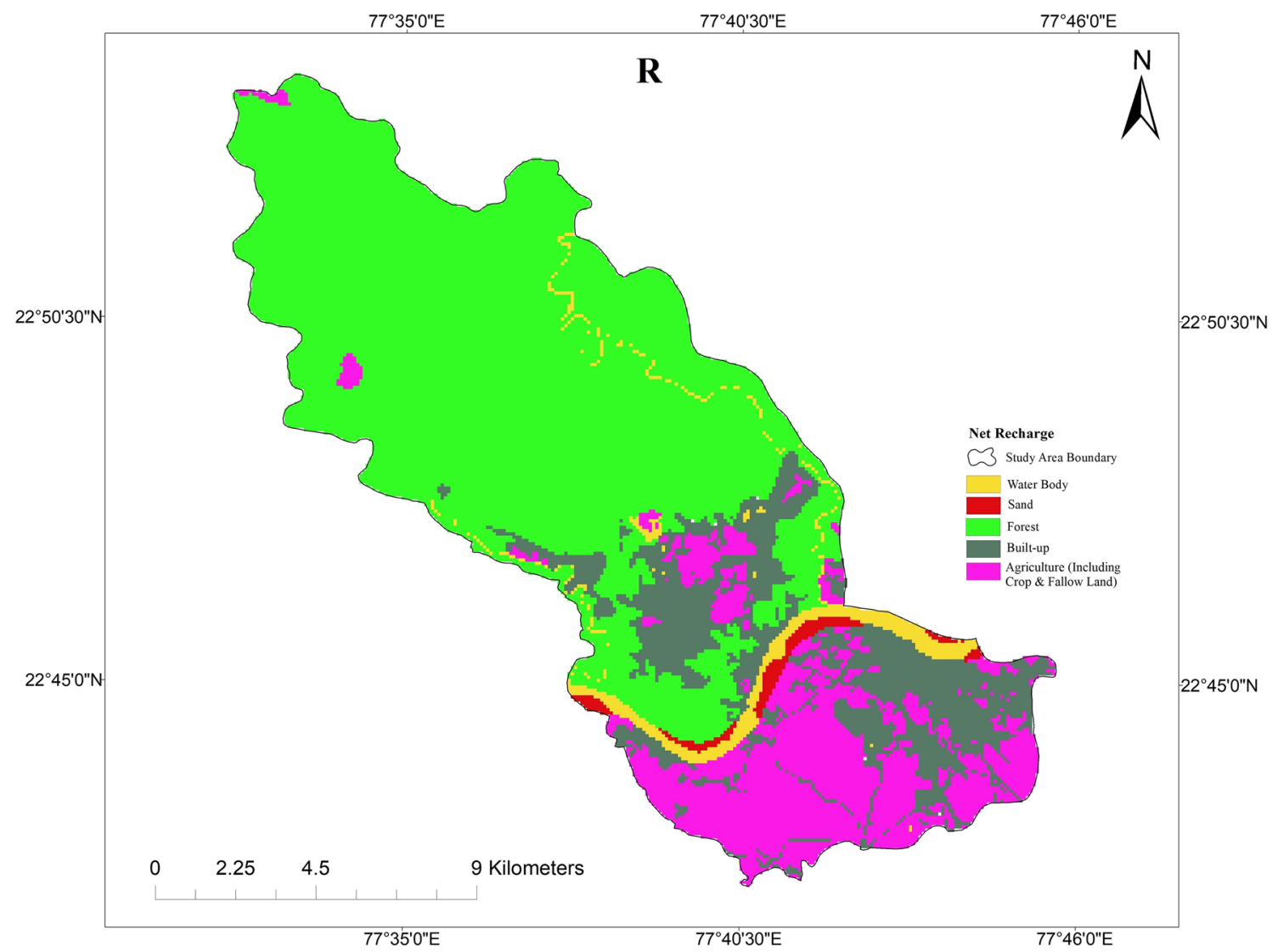

Fig. 4 Net recharge

parameter given varies from 1 (having least significance in GW contamination) to 5 (having well significance in GW contamination). Similarly, rating to each variable has been given which ranges from 1 (least significant) to 10 (most significant) (Aller et al. 1987; Kumar et al. 2015). Data collected from various sources are given in Table 1 and are presented in flow chart Fig. 2.

Finally, the output groundwater vulnerability to contamination map has been prepared by integrating all these variables by running the model using Eq. (1) as follows:

$\mathrm{DI}=D_{\mathrm{r}} D_{\mathrm{w}}+R_{\mathrm{r}} R_{\mathrm{w}}+A_{\mathrm{r}} A_{\mathrm{w}}+S_{\mathrm{r}} S_{\mathrm{w}}+T_{\mathrm{r}} T_{\mathrm{w}}+I_{\mathrm{r}} I_{\mathrm{w}}+C_{\mathrm{r}} C_{\mathrm{w}}$

where $(r)$ is rating assigned to each parameter and $(w)$ weightage assigned to each parameter of the model.

The systematic methodological approach with step-to-step process followed during the study is presented in Fig. 2.

\section{Result and discussions}

\section{Depth to water}

Depth to water represents the vertical distance from ground surfaces to the water table. It also marks the thickness of the media through which the infiltrated water has to travel to reach to the water table (Rahman 2008). Generally, the contamination chances of the groundwater become less with the extending of water table depth. In DRASTIC model, maximum weightage of 5 has been given to depth to water (Aller et al. 1987). In the study, depth to water level has been collected from the observation dug/bore wells during filed survey. Depth to water level has been measured in 26 observation wells. The minimum and maximum depth to water level recorded is $5 \mathrm{~m}$ and $15 \mathrm{~m} \mathrm{(bgl)}$, respectively. The observed depth to water level has been further divided into three categories, i.e. $0-5 \mathrm{~m}, 5-10 \mathrm{~m}$ and $>15 \mathrm{~m}$ (bgl), respectively. Ratings were assigned to each class of depth to water level. The rating of 10 was given to shallow groundwater level depth and 5 to deep groundwater level depth. The 


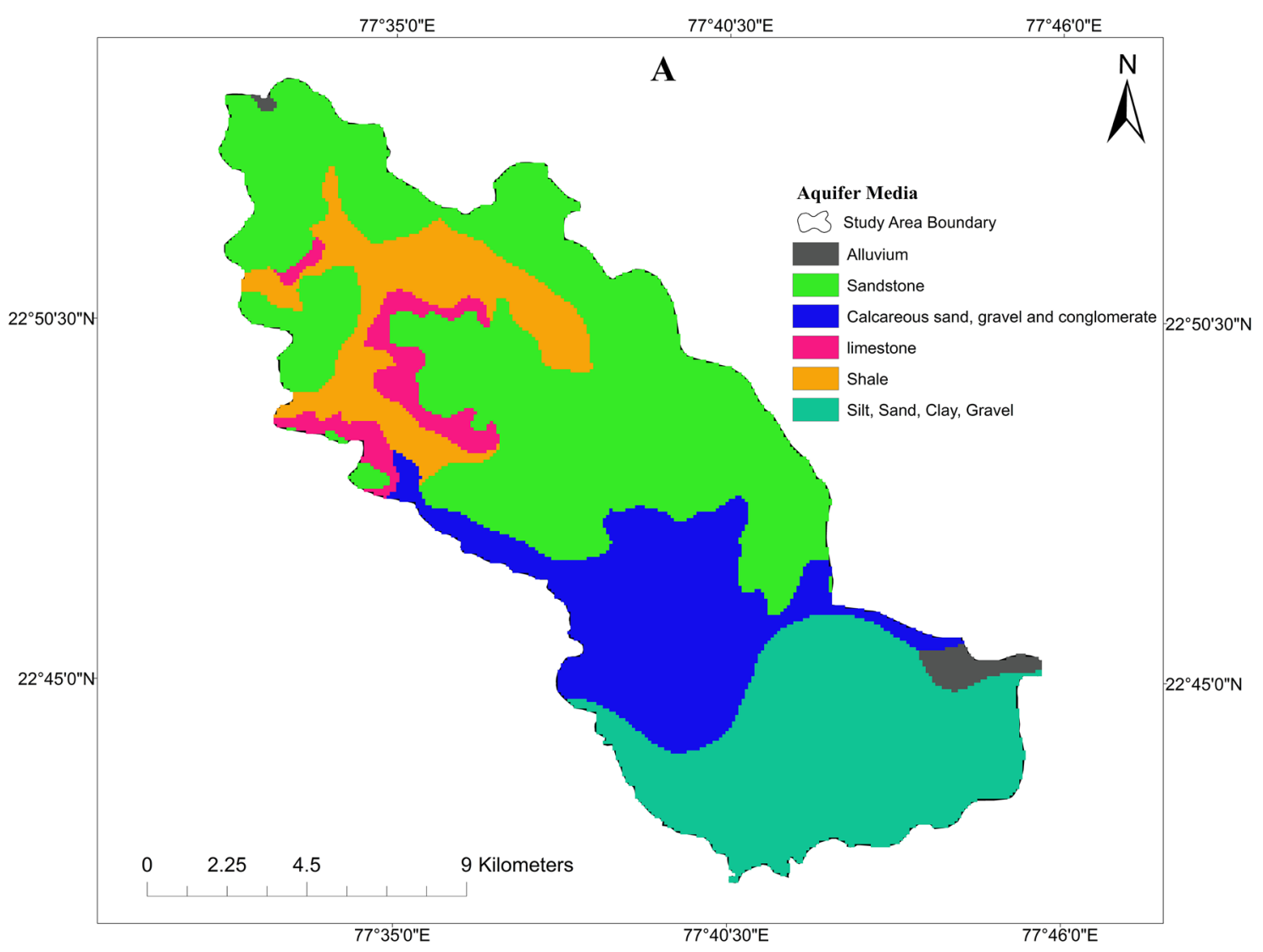

Fig. 5 Aquifer media

assigned rating, weightage and index of depth to water are given in Table 2. Depth to water level map is presented in Fig. 3.

\section{Net recharge}

The amount of water per unit area that percolates down to the groundwater on annual basis is called net recharge. Net recharge is a single medium of contaminant transporter from the ground surface through vadose zones to the water table (Yin et al. 2010). In the study, land use/land cover map has been taken in consideration for estimation of net recharge using the method suggested by (Rahman 2008). In land use/ land cover analysis, five major land cover classes have been identified in the area, i.e. water body, sand, forest, agriculture (including crop and fallow land) and built-up (Fig. 4). An extensive sandy plain tract along the river valley where net recharge was found maximum has been given the rating of 7 . The single water body present in the area has been assigned the highest rating of 8 . Low ratings were given to built-up area, because it obstructs the infiltration of water to recharge groundwater. Thus, in the study rating of 1 has been given to less recharge area and 9 to maximum recharge area.
The assigned rating, weightage and index to the net recharge are given in Table 2 .

\section{Aquifer media}

The consolidated or unconsolidated rock or soil media which composes the aquifer refers to aquifer media. This media serves to an aquifer and controls the rate of contaminant movement down to the water table. In the study, aquifer media has been derived from the existing lithology of the area. Aquifer media derived is mainly composed of (1) alluvium (2) calcareous sand, gravel and conglomerate, (3) sandstone, (4) shale (5) silt sand, clay, gravel and (6) limestone (Fig. 5). The porosity and permeability of these materials (aquifer media) is good and is capable to hold appreciable water, thus are very sensitive to groundwater contamination. Good porous aquifer media has been given to high ratings, whereas impervious aquifer media was given to low rating. Ratings were given to aquifer media, and the rating of 6 has been assigned to sandstone and 8 to limestone. The assigned rating, weightage and index to aquifer media are given in Table 2. 




Fig. 6 Soil media

\section{Soil media}

Soil media has an important role to determine the amount of recharge and potential of contaminates to reach to the groundwater. The thickness of soil influence on movement of water so on effect the movement of contaminants to groundwater (Lee 2003). In the study, soil media map has been extracted from the soil map of Madhya Pradesh (NBSSS and LUP) by extracting various soil classes present in the area. The area is characterized of two broad soil classes: (1) fine loamy and (2) loamy skeletal soil (Fig. 6). Both the soil classes possess good hydraulic properties. Fine loamy soils have occupied the southernmost part of the area along both sides of Narmada River. Loamy skeletal soils are exposed towards north-eastern side and have occupied major part of the area. Rating to soil parameter has been assigned on the basis of their permeability and texture. Rating of 4 has been given to fine loam and 10 to loamy skeletal soil. The assigned rating, weightage and index to the soil media are given in Table 2.

\section{Topography}

In the study, topography has been shown in the form of slope. Plain topography or low slope areas have capability to retain water for long time, thus enhances the recharge of groundwater as well as contaminant movement. Slope of the area has been derived by processing of the SRTM imagery in ArcGIS environment. Slope map of the area has been prepared which was further divided into five classes (Fig. 7). Most part of the area falls in low slope class where slope varies from 2 to $6 \%$. This slope class was found in groundwater dividing areas. Steep slope areas were seen along the southern marginal parts of the area. Rating of 1-10 has been given to slope parameter. High rating has been assigned to flat or plain area, because water retains there for longer time that provides sufficient time to pollutant to infiltrate into the soil and reaches to groundwater. Low rating has been assigned to steep slope areas, because it discourages the recharge practices and encourages the surface runoff processes, thus has the least chances of groundwater contamination. Rating, 


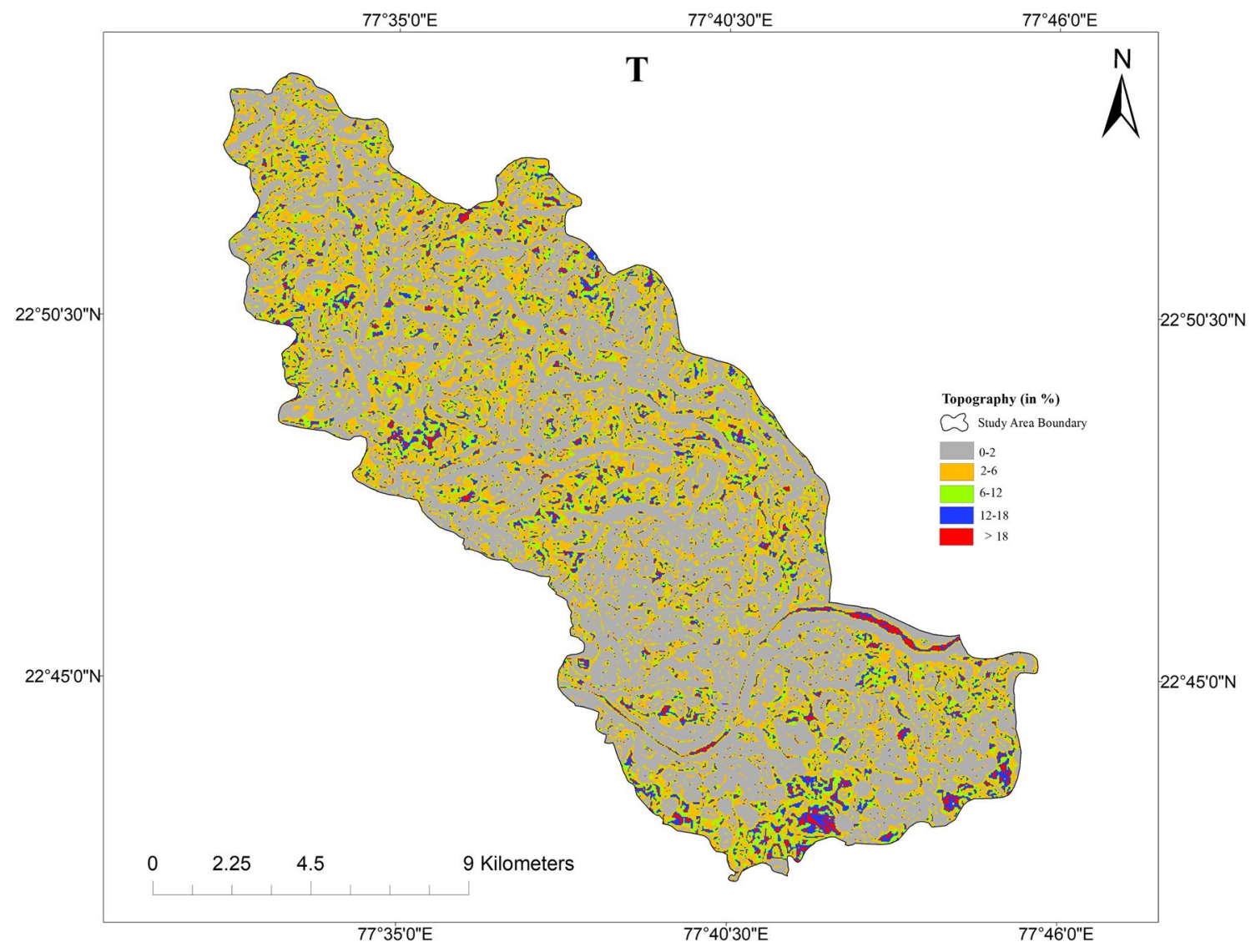

Fig. 7 Topography

weightage and index prepared for the topography parameter are given in Table 2.

\section{Impact of the vadose zone}

Vadose zone is the zone lying between the ground surface and water table. The infiltrate water has to pass through this zone to reach to water table. Thus, permeability of the material of this zone led great impact on the recharge rate and contaminant movement. Vadose zone media has been derived from the prevailing lithology of the area that comprises of alluvium, sand, silt, gravel, clay, limestone, calcareous sand, gravel and conglomerate (Fig. 8). Rating to this parameter has been given which varies from 1 to 9 . Rating of 1 was assigned to the low porous media, whereas rating of 9 has been given to the highly permeable vadose zone media. The assigned rating, weightage and index to the parameter are given in Table 2.

\section{Hydraulic conductivity}

The ability of an aquifer media (soil or rock) to allow water to pass through it is called hydraulic conductivity. Good hydraulic conductivity material has been given higher rating. This property is directly proportional to the permeability of the media. It also controls the rate of contaminant movement. Hydraulic conductivity values for the material composed the area were taken from the defined hydraulic conductivity values for different soil and rock materials (Rahman 2008). Hydraulic conductivity map of the area has been prepared which is presented in Fig. 9. Rating, weightage and index prepared for hydraulic conductivity are given in Table 2 . It has been seen that most part of the area is composed of the materials which possess good hydraulic conductivity. Rating to this parameter has been given which ranges from 3 to 10 . Low rating of 3 has been given to shale, whereas high rating of 10 to calcareous sand, gravel and conglomerate (unconsolidated porous media). 


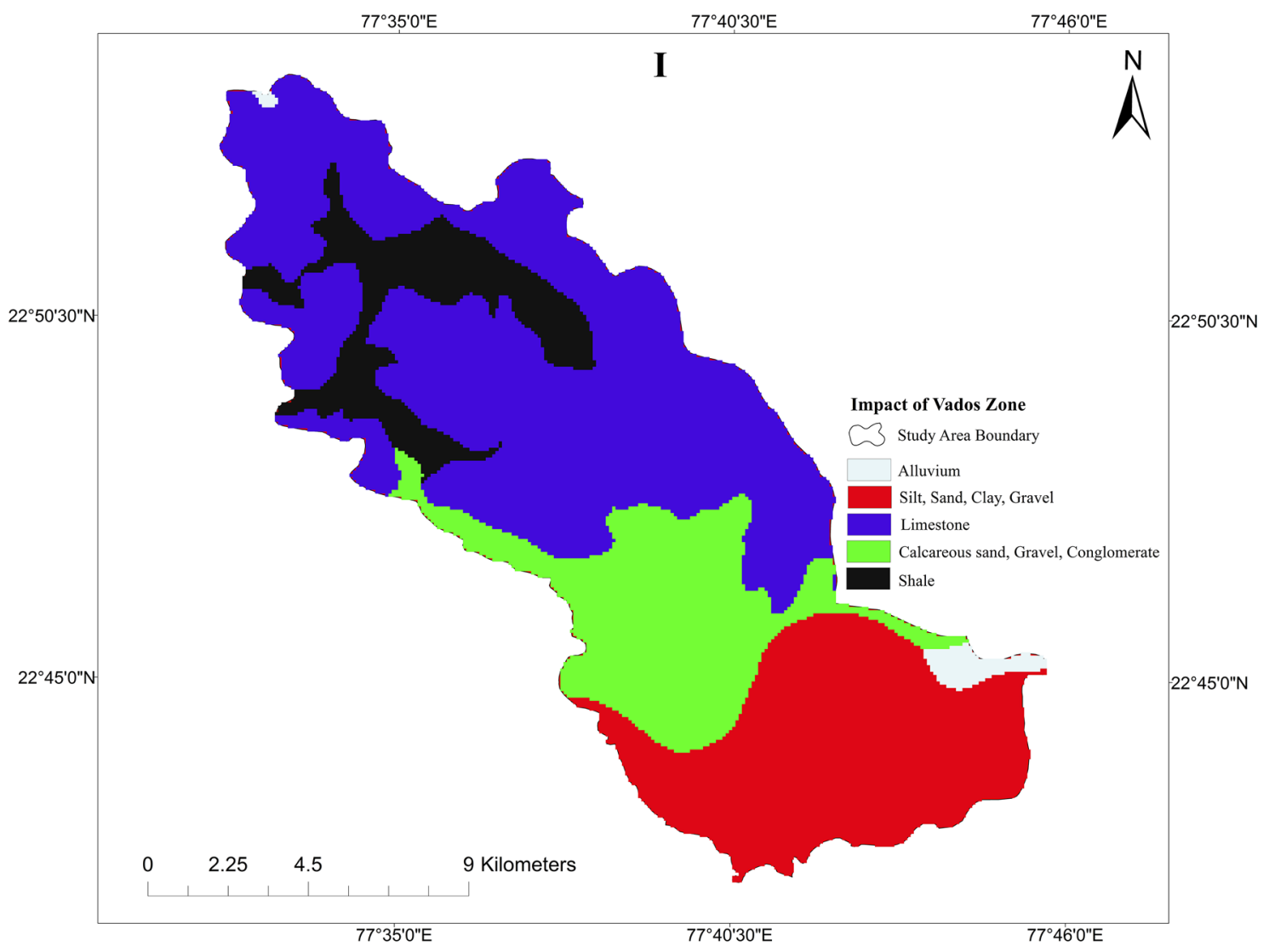

Fig. 8 Impact of vadose zone

\section{DRASTIC index}

DRASTIC index of the area has been computed by equating all seven data layers using Eq. (1). DRASTIC index of the area calculated varies from 66 to 170 which were further divided into five classes. Groundwater vulnerability map generated (Fig. 10) shows the groundwater contamination vulnerable zones. The area covered by each groundwater contamination vulnerable zone has been calculated in ArcGIS and is given in Table 3. The study reveals that 9.89\% of the area falls in very low groundwater contamination vulnerable zone, $10.52 \%$ of area falls in low groundwater contamination vulnerable zone, $42.35 \%$ area in medium GW contamination vulnerable zone, and $27.39 \%$ area comes under high GW contamination vulnerable zone and $9.85 \%$ area comes under very high GW contamination vulnerable zone (Table 3). Areas of high and very high contamination zone are mainly located in the south-eastern side of the area, where the physical factors such as plain topography, shallow groundwater depth, porous soil and aquifer media and seepage from water body favour the groundwater recharge practices. All these factors support to groundwater recharge as well as contamination in the area. The south-western part of the area falls in no risk to medium groundwater contamination zone, because of the steep topography, presence of hard rocks and impervious surfaces that discourage the groundwater recharge processes. Further, the obtained model results were validated by determining the sulphide concentration in groundwater of the identified groundwater contamination vulnerable zones. The study reveals that sulphide concentration reported in very high GW vulnerable zone varies from 14 to $17 \mathrm{mg} / \mathrm{L}$, followed by $11-14 \mathrm{mg} / \mathrm{L}$ in high, $7-11 \mathrm{mg} / \mathrm{L}$ in moderate, $4-7 \mathrm{mg} / \mathrm{L}$ in low and $1-4 \mathrm{mg} / \mathrm{L}$ in very low $\mathrm{GW}$ contamination vulnerable zone. 


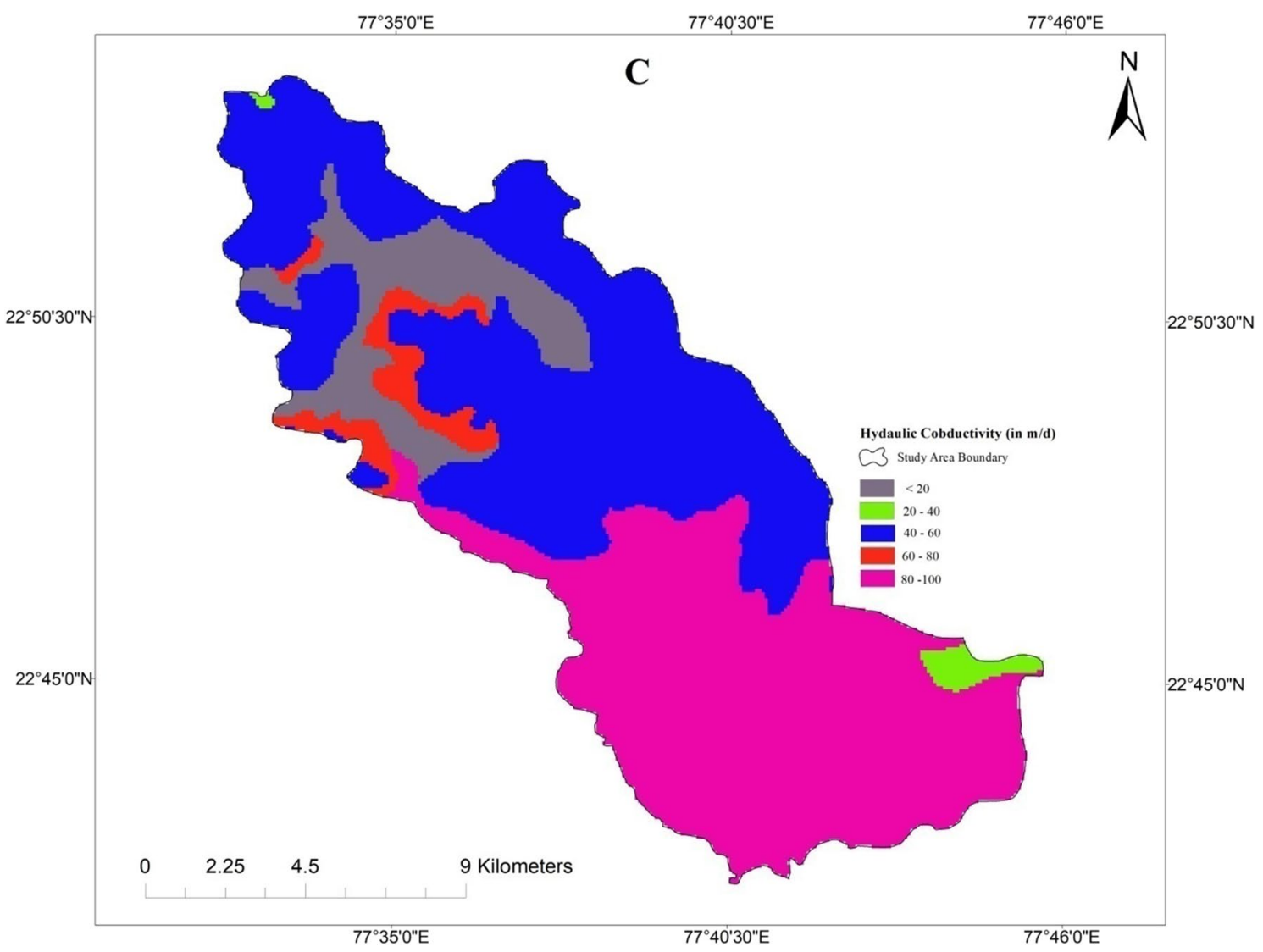

Fig. 9 Hydraulic conductivity

\section{Conclusion}

In the study, an integrated approach of GIS and field observations was carried out for the assessment of groundwater contamination vulnerability of Budhni and Hoshangabad industrial area. DRASTIC model which is based on seven hydrogeological parameters has been used to determine the GW vulnerability index of the area. The derived groundwater vulnerability index varies from 66 to 170 and was classified into five zones. The study reveals that $9.89 \%$ of the area has very least contamination chances and was demarcated as very low GW contamination vulnerability zone, $10.52 \%$ of the area comes in low GW contamination vulnerability zone, and $42.35 \%$ area falls in moderate GW contamination vulnerability zone. A major part of the area that covers $27.39 \%$ is demarcated as high GW contamination vulnerability zone, and $9.85 \%$ is under great threat demarcated as very high GW contamination vulnerability zone. Further, the model results have been validated by observed sulphide concentration in the groundwater of the delineated contamination vulnerable zones that shows sulphide varying from 1 to $4 \mathrm{mg} / \mathrm{L}$ in very low GW vulnerable zone followed by $4-7 \mathrm{mg} / \mathrm{L}$ 


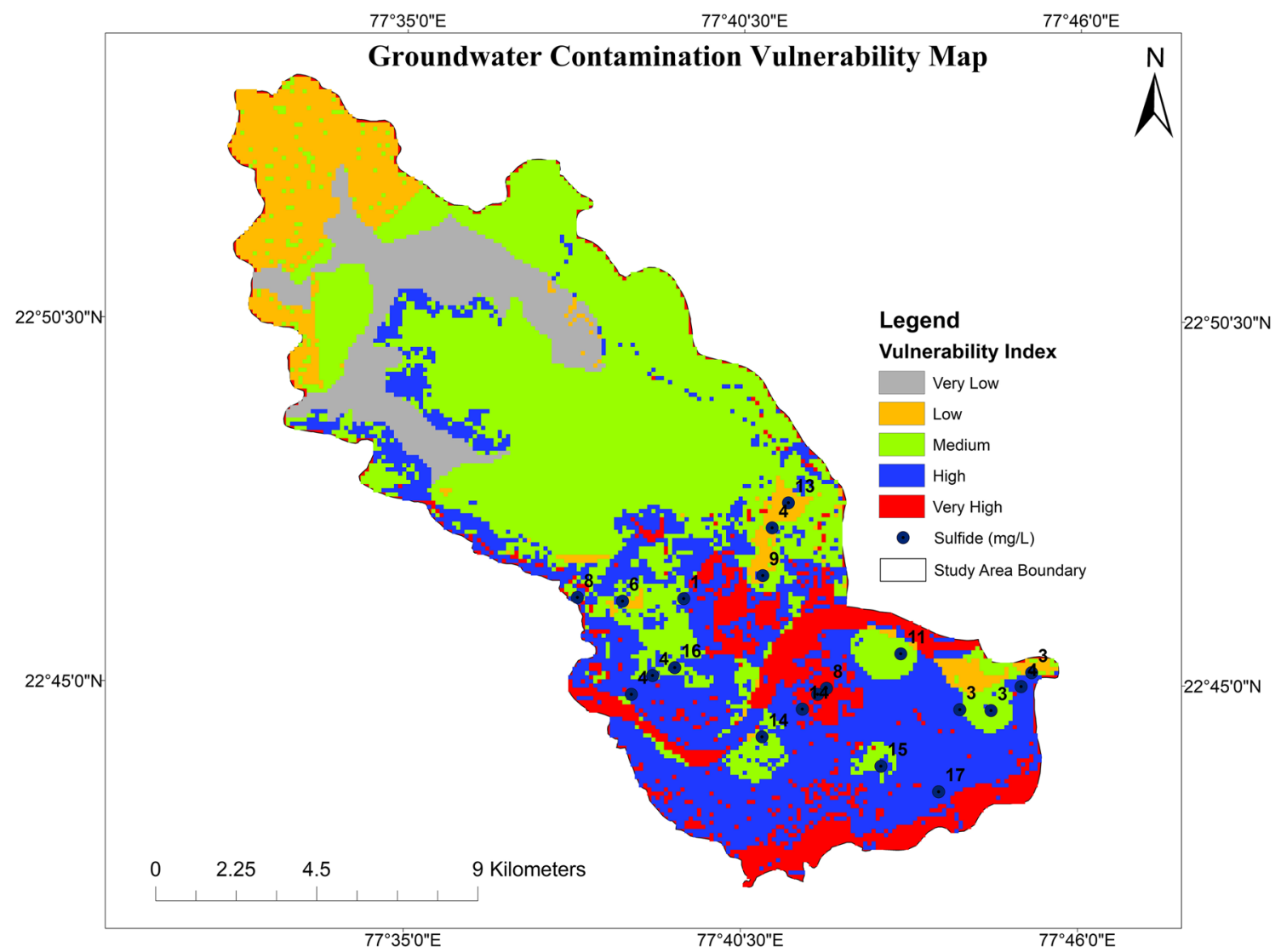

Fig. 10 Groundwater vulnerability contamination map

Table 3 Groundwater contamination vulnerability zone distribution

\begin{tabular}{llcl}
\hline DRASTIC index & Range & Area $(\%)$ & Sulphide (mg/L) \\
\hline Very low groundwater contamination potential & $66-85$ & 9.89 & $1-4$ \\
Low groundwater contamination potential & $86-110$ & 10.52 & $4-7$ \\
Medium groundwater contamination potential & $120-130$ & 42.35 & $7-11$ \\
High groundwater contamination potential & $140-140$ & 27.39 & $11-14$ \\
Very high groundwater contamination potential & $150-170$ & 9.85 & $14-17$ \\
\hline
\end{tabular}

in low, $7-11 \mathrm{mg} / \mathrm{L}$ in moderate, $11-14 \mathrm{mg} / \mathrm{L}$ in high and $14-17 \mathrm{mg} / \mathrm{L}$ in very high $\mathrm{GW}$ contamination vulnerable zone. The study has proved that the model is applicable for the existing hydrogeological setting of the area and can be used as best tool for groundwater resources management.

Acknowledgements Authors of the manuscript are thankful to coordinator AcSIR, CSIR-AMPRI and Director CSIR-AMPRI, Bhopal, for giving permission to publish this research article. Authors are also grateful to the editor and anonymous reviewers for their constructive and insightful comments and suggestions.

Funding No fund has been received for this study from any agency.

\section{Compliance with ethical standards}

Conflict of interest The authors declare that they have no conflict of interest.

Open Access This article is licensed under a Creative Commons Attribution 4.0 International License, which permits use, sharing, adaptation, distribution and reproduction in any medium or format, as long as you give appropriate credit to the original author(s) and the source, provide a link to the Creative Commons licence, and indicate if changes were made. The images or other third party material in this article are included in the article's Creative Commons licence, unless indicated otherwise in a credit line to the material. If material is not included in the article's Creative Commons licence and your intended use is not permitted by statutory regulation or exceeds the permitted use, you will need to obtain permission directly from the copyright holder. To view a copy of this licence, visit http://creativecommons.org/licenses/by/4.0/. 


\section{References}

Ahirwar S, Shukla JP (2018) Assessment of groundwater vulnerability in upper Betwa river watershed using GIS based DRASTIC model. J Geol Soc India 91(3):334-340

Al Hallaq AH, Elaish BSA (2012) Assessment of aquifer vulnerability to contamination in Khanyounis Governorate, Gaza Strip Palestine, using the DRASTIC model within GIS environment. Arab J Geosci 5(4):833-847

Albinet M (1970) les cartes de vulnérabilité des nappes d'eau souterraine à la pollution. Bureau De Recherches Géologiques Et Minières 38:1-31

Aller L, Bennet T, Lehr JH, Petty RJ, Hacket G (1984) DRASTIC: a standardized system for evaluating ground water pollution using hydrological settings. Ada, OK, USA, Prepared by the National Water Well Association for the USEPA Office of Research and Development

Aller L, Lehr JH, Petty R, Bennett T (1987) DRASTIC: a standardized system to evaluate groundwater pollution potential using hydrogeologic settings. National Water Well Association, Worthington, pp 38-57

Al-Rawabdeh AM, Al-Ansari N, Al-Taani AA, Knutsson S (2013) A GIS-based DRASTIC model for assessing aquifer vulnerability in Amman-Zerqa groundwater basin, Jordan. Engineering 5:490-504

Al-Rawabdeh A, Al-Ansari N, Al-Taani A, Al-Khateeb F, Knutsson S (2014) Modeling the risk of groundwater contamination using modified DRASTIC and GIS in Amman-Zerqa Basin, Jordan. Open Eng 4(3):264-280

Alwathaf Y, El Mansouri B (2011) Assessment of aquifer vulnerability based on GIS and ARCGIS methods: a case study of the Sana' a Basin (Yemen). J Water Resour Prot 3(12):845

Al-Zabet T (2002) Evaluation of aquifer vulnerability to contamination potential using the DRASTIC method. Environ Geol 43(1-2):203-208

Antonakos AK, Lambrakis NJ (2007) Development and testing of three hybrid methods for the assessment of aquifer vulnerability to nitrates, based on the DRASTIC model, an example from NE Korinthia, Greece. J Hydrol 333(2-4):288-304

Baalousha H (2006) Vulnerability assessment for the Gaza Strip, Palestine using DRASTIC. Environ Geol 50(3):405-414

Baalousha HM (2016) Groundwater vulnerability mapping of Qatar aquifers. J Afr Earth Sci 124:75-93

Bai L, Wang Y, Meng F (2012) Application of DRASTIC and extension theory in the groundwater vulnerability evaluation. Water Environ J 26(3):381-391

Balasubramanian A (2015) The world's water. University of Mysore, Mysore

Barroso MF, Ramalhosa MJ, Olhero A, Antão MC, Pina MF, Guimarães L et al (2015) Assessment of groundwater contamination in an agricultural peri-urban area (NW Portugal): an integrated approach. Environ Earth Sci 73(6):2881-2894

Bojórquez-Tapia LA, Cruz-Bello GM, Luna-González L, Juárez L, Ortiz-Pérez MA (2009) V-DRASTIC: using visualization to engage policymakers in groundwater vulnerability assessment. J Hydrol 373(1-2):242-255

Brindha K, Elango L (2015) Cross comparison of five popular groundwater pollution vulnerability index approaches. J Hydrol 524:597-613

Chakraborty S, Paul PK, Sikdar PK (2007) Assessing aquifer vulnerability to arsenic pollution using DRASTIC and GIS of North Bengal Plain: a case study of English Bazar Block, Malda District, West Bengal, India. J Spat Hydrol 7(1):101-121

Chandrasekar N, Selvakumar S, Srinivas Y, Wilson JJ, Peter TS, Magesh NS (2014) Hydrogeochemical assessment of groundwater quality along the coastal aquifers of southern Tamil Nadu, India. Environ Earth Sci 71(11):4739-4750

Census of India (2011) District census handbook Hoshangabad village and town wise primary census abstract, (PCA), Madhya Pradesh, 24, 1-14

Fritch TG, Mcknight CL, Yelderman JC Jr, Arnold JG (2000) An aquifer vulnerability assessment of the Paluxy aquifer, central Texas, USA, using GIS and a modified DRASTIC approach. Environ Manag 25(3):337-345

Ghazavi R, Ebrahimi Z (2015) Assessing groundwater vulnerability to contamination in an arid environment using DRASTIC and GOD models. Int J Environ Sci Technol 12(9):2909-2918

Ghosh A, Tiwari AK, Das S (2015) A GIS based DRASTIC model for assessing groundwater vulnerability of Katri Watershed, Dhanbad, India. Model Earth Syst Environ 1(3):11

Gordon B, Callan P, Vickers C (2008) WHO guidelines for drinkingwater quality. WHO Chron 38:564

Gupta N (2014) Groundwater vulnerability assessment using DRASTIC method in Jabalpur District of Madhya Pradesh. Int $\mathbf{J}$ Recent Technol Eng 3(3):36-43

Hamza MH, Added A, Rodriguez R, Abdeljaoued S, Mammou AB (2007) A GIS-based DRASTIC vulnerability and net recharge reassessment in an aquifer of a semi-arid region (Metline-Ras Jebel-Raf Raf aquifer, Northern Tunisia). J Environ Manag 84(1):12-19

Hamza SM, Ahsan A, Imteaz MA, Rahman A, Mohammad TA, Ghazali AH (2015) Accomplishment and subjectivity of GISbased DRASTIC groundwater vulnerability assessment method: a review. Environ Earth Sci 73(7):3063-3076

Harlow GE Jr, LeCain GD (1993) Hydraulic characteristics of, and ground-water flow in, coal-bearing rocks of Southwestern Virginia (No. 2388). USGPO; US Geological Survey, Map Distribution

Hasiniaina F, Zhou J, Guoyi L (2010) Regional assessment of groundwater vulnerability in Tamtsag basin, Mongolia using DRASTIC model. J Am Sci 6(11):65-78

Huang Y, Zuo R, Li J, Wu J, Zhai Y, Teng Y (2018) The spatial and temporal variability of groundwater vulnerability and human health risk in the Limin District, Harbin, China. Water 10(6):686

Jaseela C, Prabhakar K, Harikumar PSP (2016) Application of GIS and DRASTIC modeling for evaluation of groundwater vulnerability near a solid waste disposal site. Int J Geosci 7(04):558

Jasrotia AS, Singh R (2005) Groundwater pollution vulnerability using the DRASTIC model in a GIS environment, Devak-Rui watersheds, India. J Environ Hydrol 13:1-10

Kaliraj S, Chandrasekar N, Peter TS, Selvakumar S, Magesh NS (2015) Mapping of coastal aquifer vulnerable zone in the south west coast of Kanyakumari, South India, using GIS-based DRASTIC model. Environ Monit Assess 187(1):4073

Kanade PS, Bhattacharya SS (2016) A guide to filtration with string wound cartridges: influence of winding parameters on filtration behaviour of string wound filter cartridges. Elsevier, New York

Kim YJ, Hamm SY (1999) Assessment of the potential for groundwater contamination using the DRASTIC/EGIS technique, Cheongju area, South Korea. Hydrogeol J 7(2):227-235

Kumar P, Bansod BK, Debnath SK, Thakur PK, Ghanshyam C (2015) Index-based groundwater vulnerability mapping models using hydrogeological settings: a critical evaluation. Environ Impact Assess Rev 51:38-49

Kumar P, Thakur PK, Bansod BK, Debnath SK (2016) Assessment of the effectiveness of DRASTIC in predicting the vulnerability of groundwater to contamination: a case study from Fatehgarh Sahib district in Punjab, India. Environ Earth Sci 75(10):879

Lee S (2003) Evaluation of waste disposal site using the DRASTIC system in Southern Korea. Environ Geol 44(6):654-664

Leone A, Ripa MN, Uricchio V, Deak J, Vargay Z (2009) Vulnerability and risk evaluation of agricultural nitrogen pollution for

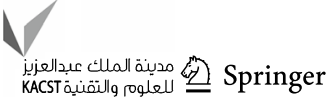


Hungary's main aquifer using DRASTIC and GLEAMS models. J Environ Manag 90(10):2969-2978

Margat J (1968) Vulnerabilite desnappes d'eau souterraineala pollution. Basede lacartographie, Doc. BRGM, 68 SGL 198 HYD. Orlean, France

Malik MS, Shukla JP (2019) Assessment of groundwater vulnerability risk in shallow aquifers of Kandaihimmat Watershed, Hoshangabad, Madhya Pradesh. J Geol Soc India 93(2):199-206

Meng SH, Fei YH, Zhang ZJ, Qian Y, Li YS (2011) Groundwater vulnerability assessment of North China Plain. Geol China 38(6):1607-1613

Mogaji KA, Lim HS, Abdullah K (2014) Modelling groundwater vulnerability prediction using geographic information system (GIS)based ordered weighted average (OWA) method and DRASTIC model theory hybrid approach. Arab J Geosci 7(12):5409-5429

National Bureau of Soil Sciences and Land use Planning (NBSS\&LUP, ICAR, Nagpur), 1996 Soils of Madhya Pradesh, vol. 59 NBSS Publ

Neshat A, Pradhan B, Dadras M (2014a) Groundwater vulnerability assessment using an improved DRASTIC method in GIS. Resour Conserv Recycl 86:74-86

Neshat A, Pradhan B, Pirasteh S, Shafri HZM (2014b) Estimating groundwater vulnerability to pollution using a modified DRASTIC model in the Kerman agricultural area, Iran. Environ Earth Sci 71(7):3119-3131

Panagopoulos GP, Antonakos AK, Lambrakis NJ (2006) Optimization of the DRASTIC method for groundwater vulnerability assessment via the use of simple statistical methods and GIS. Hydrogeol J 14(6):894-911

Prasad K, Shukla JP (2014) Assessment of groundwater vulnerability using GIS-based DRASTIC technology for the basaltic aquifer of Burhner watershed, Mohgaon block, Mandla (India). Curr Sci 107(10):1649-1656

Prasad RK, Singh VS, Krishnamacharyulu SKG, Banerjee P (2011) Application of DRASTIC model and GIS: for assessing vulnerability in hard rock granitic aquifer. Environ Monit Assess 176(1-4):143-155

Qian H, Li P, Howard KW, Yang C, Zhang X (2012) Assessment of groundwater vulnerability in the Yinchuan Plain, Northwest China using OREADIC. Environ Monit Assess 184(6):3613-3628

Rahman A (2008) A GIS based DRASTIC model for assessing groundwater vulnerability in shallow aquifer in Aligarh, India. Appl Geogr 28(1):32-53
Rebolledo B, Gil A, Flotats X, Sánchez JÁ (2016) Assessment of groundwater vulnerability to nitrates from agricultural sources using a GIScompatible logic multicriteria model. J Environ Manag 171:70-80

Rosen L (1994) A study of the DRASTIC methodology with emphasis on Swedish conditions. Groundwater 32(2):278-285

Samake M, Tang Z, Hlaing W, Innocent NDOH, Kasereka K, Balogun WO (2011) Groundwater vulnerability assessment in shallow aquifer in Linfen Basin, Shanxi Province, China using DRASTIC model. J Sustain Dev 4(1):53

Secunda S, Collin ML, Melloul AJ (1998) Groundwater vulnerability assessment using a composite model combining DRASTIC with extensive agricultural land use in Israel's Sharon region. J Environ Manag 54(1):39-57

Sener E, Sener S, Davraz A (2009) Assessment of aquifer vulnerability based on GIS and DRASTIC methods: a case study of the SenirkentUluborlu Basin (Isparta, Turkey). Hydrogeol J 17(8):2023

Shrestha S, Semkuyu DJ, Pandey VP (2016) Assessment of groundwater vulnerability and risk to pollution in Kathmandu Valley, Nepal. Sci Total Environ 556:23-35

Sinha MK, Verma MK, Ahmad I, Baier K, Jha R, Azzam R (2016) Assessment of groundwater vulnerability using modified DRASTIC model in Kharun Basin, Chhattisgarh, India. Arab J Geosci 9(2):98

Thukral KR, Rahman S (2017) Madhya Pradesh assembly factbook, Hoshanagabad assembly constituency, compiled, researched and published by datanet India Pvt. Ltd., 1-27. http://www.datanetind ia-ebooks.com

Tirkey P, Gorai AK, Iqbal J (2013) AHP-GIS based DRASTIC model for groundwater vulnerability to pollution assessment: a case study of Hazaribag district, Jharkhand, India. Int J Environ Prot 3(9):20

Yin LH, Hou GC, Tao ZP, Li Y (2010) Origin and recharge estimates of groundwater in the Ordos Plateau, People's Republic of China. Environ Earth Sci 60(8):1731-1738

Yin L, Zhang E, Wang X, Wenninger J, Dong J, Guo L, Huang J (2013) A GIS-based DRASTIC model for assessing groundwater vulnerability in the Ordos Plateau, China. Environ Earth Sci 69(1):171-185

Publisher's Note Springer Nature remains neutral with regard to jurisdictional claims in published maps and institutional affiliations. 